\title{
146.
}

$616.662-003 \cdot 7$

包皮內結石知見補遺

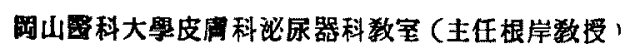

助手 學士 伊藤誠爾

[昭和 12 年 10 月 21 日受柯]

Aus der Dermato-Urologischen Klinik der Medizinischen Fakultat Okayama.

(Vorstand: Prof. Dr. Hirosi Negisi)

Über Praputialstein.

Von

Dr. Seiji Ito.

Eingegangen am 21. Oktober 1937.

Ioh hatte neuerdings Gelerrenheit, eiuen Fall von sogr. Präputialsttin eingehend zu beobachten. Es handelte sich um einen 40-jährigen Bnuer nit angeborener Phimose. Der Patient machte seit 5 Jahren auf einen kleinen schmerzlosen Knoten am Frenulum aufmerksam, der sich allmählich ver.roosserte. Währeıd des Verlaufs trat eine Entzündung der Vorhaut auf, dnzu kam eine Miktionsstorung. Bri der Palpation zeigt sich dort eine bohnengrosse Induration, die sich knocheshart ufühlt. Der Präputial ring ist so verengert, dass eine Sonde Nr. 6. Charrière mit Mäh darin eingeführt werden kann und dabei fühlt man einen harten Korper durch, den ich als Präputialkonkrement deuten zu müssen glaube. Der durch Circumzision exstirpierte Stein ist flach oval, grauweiss, hart und von glatter Oberfläche. Er ist $1,24 \mathrm{~cm}$ lang, $1,05 \mathrm{~cm}$ breit, $0,62 \mathrm{~cm}$ dick und wiegt $0,6 \mathrm{~g}$. Seine chemische Zusanmensetzung besteht aus Carbonat- Phosphat- Oralatkalk und Magnesiumphosphat. Die Schnittfläche des Steins weist eine konzentrische Ringschicht auf.

Ich habe ferner einen statistischen Überblick über das Leilen gemacht, indem ich die gesamte Literatur, besonders aber die in Japan darüber veroffentlichten Angaben semmelte und kurz gefasst folgendermassen zusammeustellte. 
1) Unter 10420 urologischen Kranken, die bei uns in den letzten 17 Jahren und 8 Monaten beobachtet wurden, findet sich der Präputialstein nur einmal und das Verhältuis zu geworhnlichem Harnstein ist $1: 455$.

2) Die Zahl aller Fälle von Präputialstein in Japan beträgt nur 14 mit Einschluss meiues Falls. Diesen verteilen sich auf folgende Lebensperioden.

$\begin{array}{cccc}\text { unter 10. Jahr } & 1 & \text { über 50. Jahr } & 4 \\ \text { 2. Dezennium } & 3 & \text { unklar } & 2 \\ \text { 3. } " & 0 & & \\ \text { 4. } " & 4 & & \end{array}$

3) In Japan zeigt sich in den einzelnen Fällen gewobnlich nur ein einziger Präputialstein, wogegen sie in Europa oder Amerika meist zallreicher auftreten. Der Fall mit zahlreichsten Präputialstein in Japan (Ikedascher Fall) zählte 12 solcher Steine.

4) Dns Gewicht der einzelnen Steine schwankt je nach dem Fall merklich, im allgemeinen aber ist es viel leichter als das der Harnsteine, der schwerste Fall (Hasimotoscher Fall) in Japan wog $42,0 \mathrm{~g}$.

5) Ihrer Entstehung nach werden die Präputialsteine in 2 Gruppen eingeteilt, nämlich in primäre und sekundäre Steine. Die ersteren stellen sich als solche dar, die sich von Anfang an im Präputialsack entwickeln, die letzteren als solche, die von Harnwegen kommen. Die primären Steine werden ferver je nach dem Kern in 2 Unterklassen differenziert, nämlich in solche, bei denen der Kern aus Smegma und Epithelien etc. gebildet ist, und in solche, bei denen er aus dem im Präputialsack gesammelten Harnsalz besteht. Diese verschiedenen Arten sind in ihrer Beschaffenheit wohl voneinander zu unterscheiden; mein Fall gehort zu den zuletzt genanten.

6) Der Präputialstein ist inmer von der Phimose begleitet, doch ist diese natürlich nicht als die eigentliche Ursache der Krankheit anzusehen.

7) Jeder Präputialstein sollte so rasch wie moglich entfernt werden. Bei der Operation ist besonders auf eine strenge Aseptik zu achten. Es empfiehlt sich, die extreme Phimose frühzeitig zu operieren, weil dadurch verschiedenen Infektionen und der Steinbildung vorgebeugt werden kann. (Autoreferat)

内容目次

1. 緒 言

2. 自家症籿

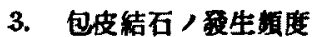

4. 包皮結石八数，大サ，重量

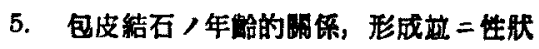

6. 包皮結石应 八定肰

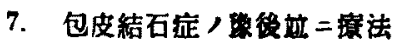

8. 括及ビ結諭 主要交代 
1. 緒 言

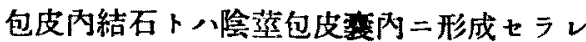
タル結石叉八結石樣凝塊ノ称ニシテ極メテ稀 有ナル疾患二屬ス。偶々余八最近其， 1 例

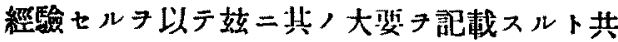

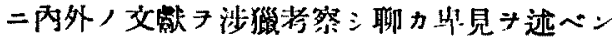
卜欲ス.

\section{2. 自家症例}

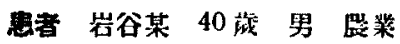

初猃 昭和 11 年 12 月 22 日

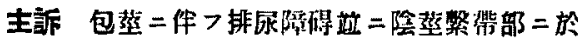
ケル硬結

家族歴 同胞八患者共 $=2$ 人，技卜ノ間二八4 人/子供フリ。總テ健全ニシテ家疾間二結核性愚 者其,他傳染生突患ナシ。

既往症 患者八生來强健ニシテ幼時 $コ$ リ著患 知ラズ．生來中等度／先天性包蕉 有セシモ何等

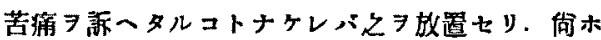
花略病二就テハ㥛力之ヨ否定セり。

現病屋 約 5 年前二可等原因卜思八ル几動機ナ

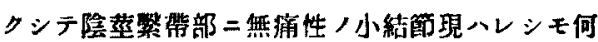
等自覺的症状 7 呈セズシテ經過セり．然儿二其，

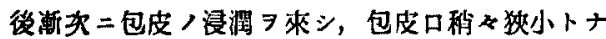
リ，包皮，醀轉モ亦多少困蜼 加フル二爾來尿線細小トナリ排尿二長時間 7 姴 テ快利せザルモ別 ニ大ナル苦痛ヨ感ズル二至ラザ リシママ自然二战置七シニ, 特=2 简月前 $コ$ リ病

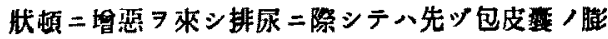
路习見，次デ極メテ細小ナル尿線ニシリテ放尿ス レドモ而モ尿線八直射七ズ，時二八左方二時二八 在方二倔射シ，或八尿線／分岐スルラ見ルコトサ ーアリトイフ。而シテ放尿縃末二於テ八放尿力堿

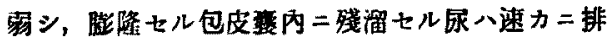

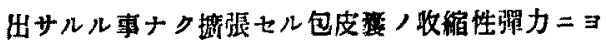

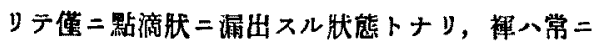

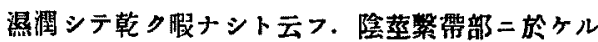
硬結物モ增大シテ繁豆大以上ノ大サトナリシモ該

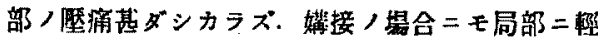
度ノ疼演习感ズル程度ナリシト調つ。

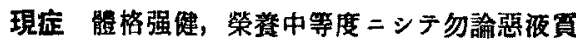

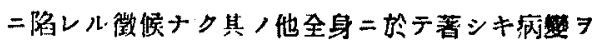
認メズ. 局所ヨ見ル二包皮八慢性炎症性ノ極端ナ

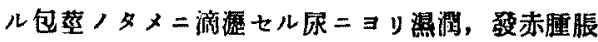

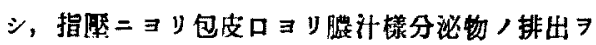
見几、陰䔲/形状八圆錐形二シテ恰モ彈丸 媔點

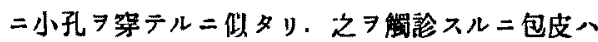
一橉二浸润肥厚シテ硬ク, 其 /先端二至ル二從上

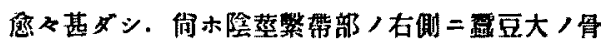

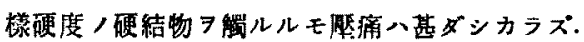
包皮口八惯メテ狟小トナリ包皮习如何二强ク後方

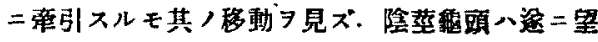
見シ得ズ．包皮ロヨリシャリエーNr. 6 ，消息了

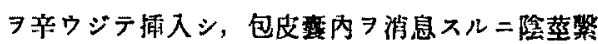

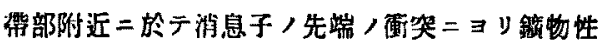
晋习聞キ明ラカ二固形硬固物，存在 $习$ 感的セリ。

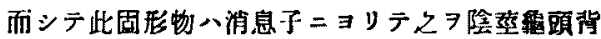
例マデ移動セシムルコトヨ得レドモ更二西頭背则 ヨ越エテ此固形物 シシテ包皮震內

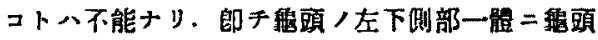
及ビ包皮內菒，虑着フルョ想淥スルニ難カラズ. 向木雨鼠躁部二八祲豆大八淋巴腺腫脤 $72-3$ 简 觸ルルモ歴痛习認メズ、

尿所見八 1 国／排尿量僅少ニシテ 2 杯試驗 7 行 フニ八アマリ意味ナキモ第 1 杯，第 2 杯共二润㯰

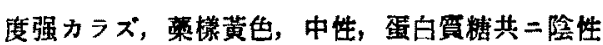
ナリ、顯微鏡的所見トシテ八多核白血球 $(+)$, 單 核白血球 $(+)$, 扁 $4^{5}$ 上皮細胞 $(+)$ ，赤血球 $(-)$ ， 淋菌(一)，尿球菌(十)ナリ.

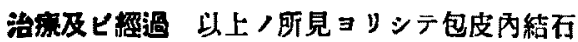


，診断 ノ下二局所麻醉下二環肤包皮切除法 容易二結石习除去シ得タルノミナラズ，其 /後何

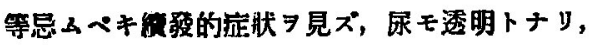
排尿二際シテモ何等支障ナク，極メテ正常トナレ リ. 術後 8 日ニシテ手術偤八完全二治愿セリ. 莎 二於テサシモ永年思者 シシテ除去セラレタリ.手街時ノ所見八鼻頭及ビ

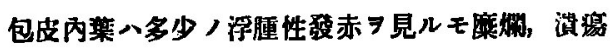

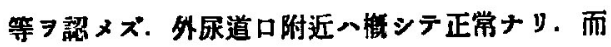

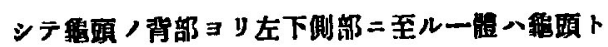

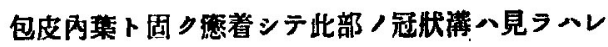

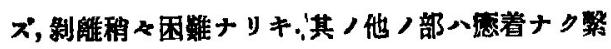
带右側部二介在七ル結石八容易二除去シ得タリ。

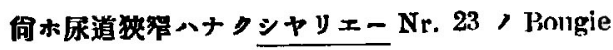
$\exists$ 容易二尿道內二押入スル

摘出セル結石、1筬ニシテ第 1 图及ビ第 2 圆二 第 1 圖 龜頍二面七ル側

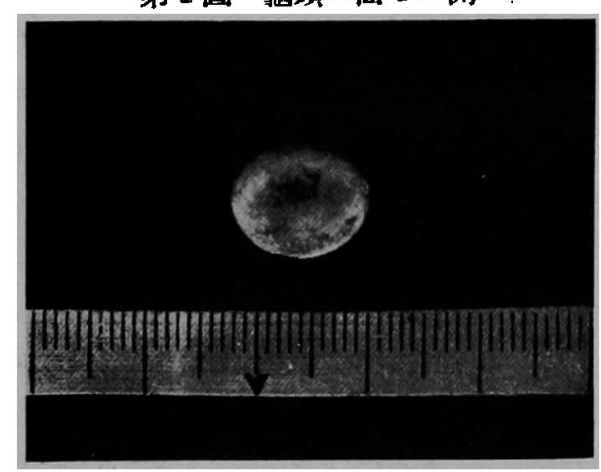

第2 圖 包皮二面七ル側

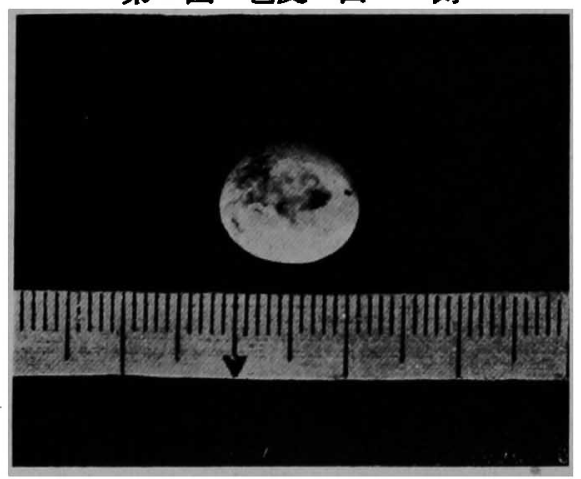

示セル如ク大サ, 形狀恰モ䍐元豆二類似シ，扁平

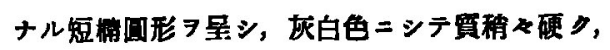
其 ノ我頭二面セシ时 /中央部稍を䧄凹シ，包皮內 葉二面セシ即 /中央部二八小突起 7 見ル. 結石

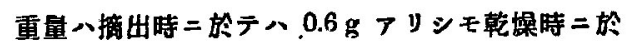
テ測定シタル $=0.564 \mathrm{~g}=$ 減少セリ。 結石 /長经 $1.24 \mathrm{~cm}$, 㛒徑 $1.05 \mathrm{~cm}$, 厚艺 $0.62 \mathrm{~cm} *$ v. 截断 面八第 3 圖二見ル如ク中心部二灰黃色，部分 7 諰

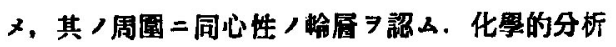
八結果一炭酸石灰，橉酸石灰，「橉酸マグネシウ ム」, 萑酸石灰等ナリ。

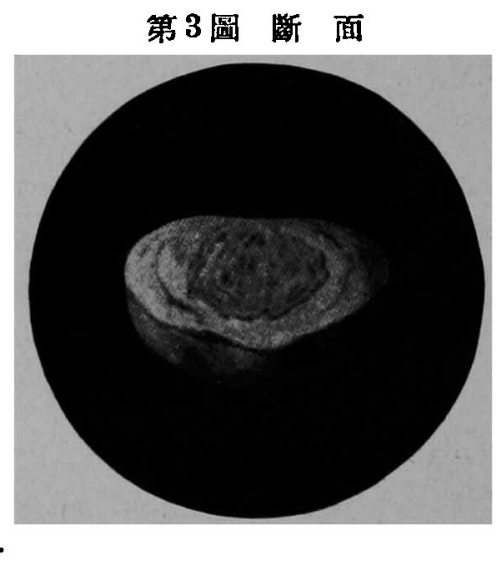

\section{3. 包皮內結石八發生頻度}

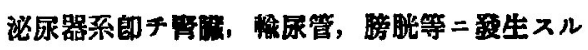

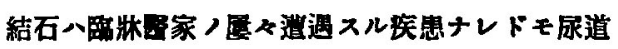
結石一此筫的少ク，包皮肉結石二至りテハ更二展 有ナル智患二雨ス. 本那二於ケル包皮結石 報告 例モ余ノ知レル籍壃二於テ八僅二13 例二過ギズ. 欧米二於テモ其 ノ報告例極メテ少り Albers 氏，

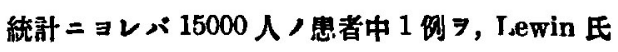

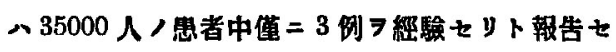

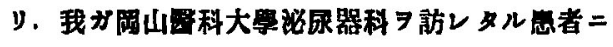
就テ見ル 至ル 17 年 8 简月間二於ヶル 全淡尿器科患者 10420 人 シシテ淡尿器系結石思者数ハ455名ナリ。 


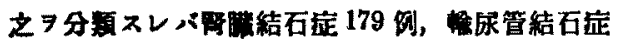

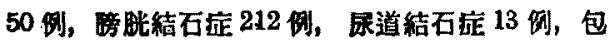

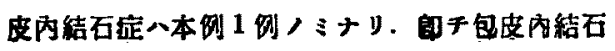
八椣メテ桸有ナル疾思ナリ。

\section{4. 包皮內結石/數，大サ重量}

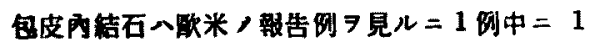

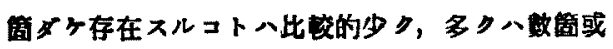

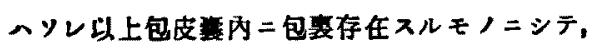

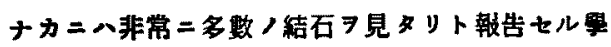
者アע，本那二於テ八挋米ノモノニ反シ，第 3 表

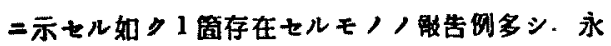
石氏モ通常 1 策ナル熶合多シト云へリ

結石ノ大サ八通常韵豆大乃至豆豆大ヨ越ニルコ

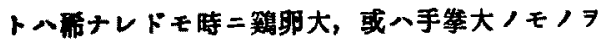
見タル者アン。

又結石，重量二於テへ他证尿器系結石二比スレ バー段二少キモノナルモ，時二八櫂り程大ナルモ

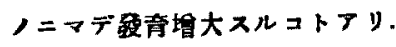

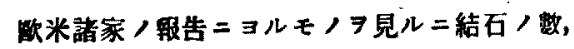

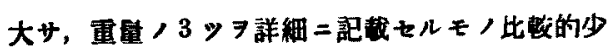

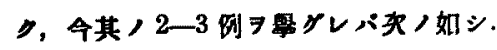

Levavasseur 氏 ( 1 涌, $210 \mathrm{~g}$ ), Mathew 氏 (1简， $222 \mathrm{~g})$ ，Vazetii 氏 (1 箇, $224 \mathrm{~g}$, 長徑 $8 \mathrm{~cm}$, 短徑 $6 \mathrm{~cm}$, 輛四形)，Couilland 氏 (1 简, $645 \mathrm{~g}$, 手学 大), Buchelmann 氏 (2 简, 直彺 $5.2 \mathrm{~cm}+3.5 \mathrm{~cm}$ 卜人球形)，Jenskins 氏 (2 简，辰俓 $2 \mathrm{~cm}$, 短理 $1 \mathrm{~cm})$, Williamson 氏 (5 简, 最大ナルモ/ 八直彺 $7 \mathrm{~mm}$ ), Nelson 氏 (38简)，Ramaroni 氏(45 瞴， 電量 $2.72 \mathrm{~g}$ ), MoCranken 氏 (395 自), Rivoir

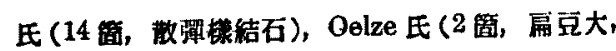
$4.7 \mathrm{~g}$ ), 8abatier 氏(重量 $24 \mathrm{~g}$ 卜 $93 \mathrm{~g}$ 卜 2 第),

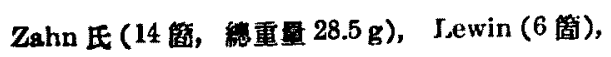
Ingraham 氏(1072筒，螕電殗 $76 \mathrm{~g}$ 大ナルモく 7 商フリ.) Ingraham 氏 7 简ノ犬ナル结石八夷
如シト.

\begin{tabular}{|c|c|}
\hline 1) & $2.7 \times 2.0 \times 1.5 \mathrm{~cm}$ \\
\hline .2) & $2.4 \times 1.5 \times 1.0 \mathrm{~cm}$ \\
\hline 3) & $2.2 \times 2.11 \times 1.7 \mathrm{~cm}$ \\
\hline 4) & $2.0 \times 1.7 \times 1.2 \mathrm{~cm}$ \\
\hline 5) & $1.9 \times 1.5 \times 1.0 \mathrm{~cm}$ \\
\hline 6) & $1.7 \times 1.5 \times 0.9 \mathrm{~cm}$ \\
\hline 7) & $1.5 \times 1.4 \times 0.8 \mathrm{~cm}$ \\
\hline
\end{tabular}

Griewank 氏八更二䄪 1800-2000简, 的重量

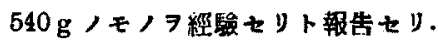

中野氏／蒐集セ儿 500 议尿器系結石中最大

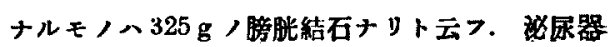
系中二生ゼシ結石ニシテ世界最大ナルモハ八月 八所ジプソトレン物馆二フル1596 $\mathrm{g}$ ，㭶脂結 石ナリト踓モ Couilland 氏 報告セル $645 \mathrm{~g} /$ 他

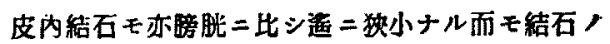
發育二條件惡シキ堨所ニ生ぜシモノトシテの世二

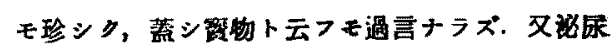

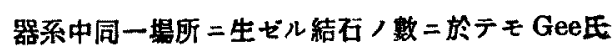

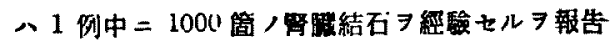
セルモ Ingraham 氏，1072䈯，Griewank 氏，

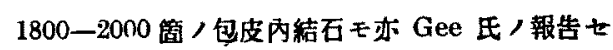

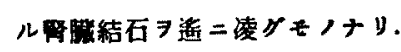

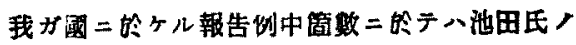
報告セル12简，包皮內結石习以テ最多トナス１ 简 /結石，重量二於テ最大ナル八霹本氏，報告せ

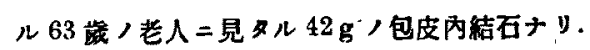

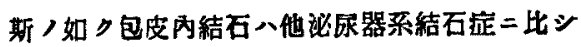
其 發生頻度二於テコソ電メテ少キモノナレドも

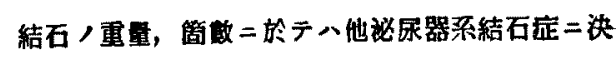
シテ多ラヌモノナリ．以上諸列二照篮シテ見ル 二一般二多蚊同時二存在スル結石ハ小ニシテ厓た

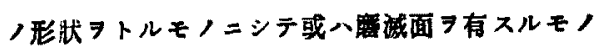
マリ.之二反シテオナル結石八迎常同時二多数存 在セザルモノナリ. 
5. 包皮結石ノ年䶖的關係, 形成 立二性狀

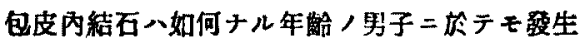
シ得ルモノナレドモ L.ewin氏八成人二多ク笔人及 ビ小兒二八比較的少シト云へルモ，Oelze 氏八成 人ヨリモ却テ小兒二多シト云フ. 蓝シ小兒二八包 菎习有スルモノ多キニ依ルナランカ. Demarquey I.ewin，Englisch 氏等，52 例二就テ報告セル包

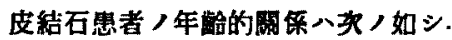

\begin{tabular}{|c|c|c|c|}
\hline & 路 & 患 & 者 \\
\hline \multicolumn{4}{|c|}{ 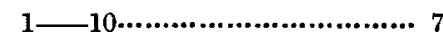 } \\
\hline \multicolumn{4}{|c|}{ 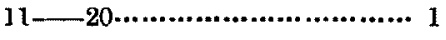 } \\
\hline \multicolumn{4}{|c|}{$21-30 \ldots \ldots \ldots \ldots \ldots \ldots \ldots \ldots$} \\
\hline \multicolumn{4}{|c|}{ 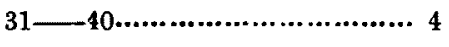 } \\
\hline \multicolumn{4}{|c|}{ 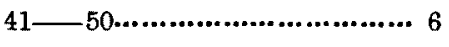 } \\
\hline \multicolumn{4}{|c|}{ 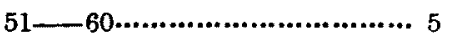 } \\
\hline \multicolumn{4}{|c|}{$61-70 \ldots \ldots \ldots \ldots \ldots \ldots \ldots \ldots \ldots \ldots$} \\
\hline \multicolumn{4}{|c|}{$71-80 \ldots \ldots \ldots . . . . . . . . . . . . . . . . . . . . .2$} \\
\hline & & & \\
\hline
\end{tabular}

本那ニ於テ八今日マデニ報告セラレタルモノ一

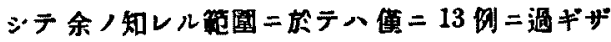
レドモ其／中小兒八佐藤那夫氏，報告セル5 藏 患者 1 侧ノミ，2侧八年路不明ニシテ他，10例八 總テ成人及ビ老人ナリ、今之等 13 例卜余ノ阴ト 合七螕計 14 例/各々報告年代，報告者，患者/年

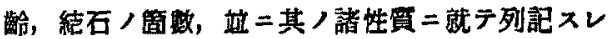
第 3 表ニ示セルガ如シ.

\section{（第 3 表被）}

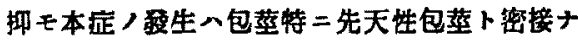

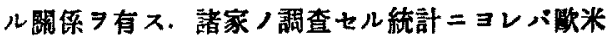
人八本那人二比シ包蕉习有スル者遥二多ケレパ歌 米人二八本那人二於ヶルヨり包包成結石患者多 數ナルコト想定サル. 事家歐米二於ヶル包皮內結

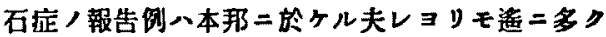
最早 100 侧以上二モ達セルト信ズ. 又 l.ewin 氏八 支那人 =八包蕉者比輘的多ク，從テ支那人二八本 底 9 多ク見ルト云ーリ。

第 3 表 本邦二於ヶル向皮內結石，報告者，弡表年代，患者，年齡，

結石, 数及ビ其ノ性狀

\begin{tabular}{|c|c|c|c|c|c|c|c|c|c|c|}
\hline 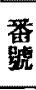 & 報告者 & 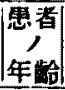 & 結石 & 結石ノ大サ & 狀 & 重 熙 & 硬度 & 色蠆 & 成 & 酸表年代 \\
\hline 1 & 村 & 41 & 1 & 腸卵大 & 埆阅形 & - & 硬 & 灰白色 & - & 明治 40 年 \\
\hline 2 & 桐 & 50 & 1 & 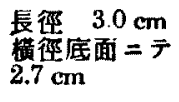 & 國雓形 & $14.5 \mathrm{~g}$ & 稳々㺿 & 灰泉 & 镂酸蟞 & 明治 41 年 \\
\hline 3 & 永 石 & 53 & 1 & 周国 $6.0 \mathrm{~cm}$ & 一 & $3.5 \mathrm{~g}$ & 硬固 & 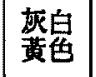 & 噒酸監類 & 明治43年 \\
\hline 4 & 橋 & 63 & 1 & 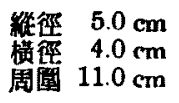 & 图笙形 & $42.0 \mathrm{~g}$ & 硬固 & 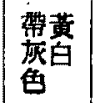 & 橉酸簬 & 明治44年 \\
\hline 5 & 宮 渏 & 63 & 1 & $\begin{array}{r}\text { 大豆大=シテ } \\
\text { 長覆 } 0.8 \mathrm{~cm} \\
0.6 \mathrm{~cm}\end{array}$ & 橙冢 $=$ 類 $ᄌ$ & 0.12 & |恢几硬 & $\begin{array}{l}\text { 滑澤 } \\
\text { 栬 } \\
\text { 色 }\end{array}$ & 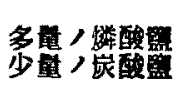 & 大正 2 年 \\
\hline
\end{tabular}




\begin{tabular}{|c|c|c|c|c|c|c|c|c|c|c|}
\hline 番 & 報告者 & $\mid$ & 結石 & 結石ノ大サ & 形猋 & 重 望 & 硬度 & 色调 & 成 & 眺表年代 \\
\hline 6 & 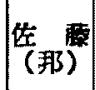 & 27 & 10 & 大小種々 & - & $\begin{array}{l}\text { 總重量 } \\
1.0 \mathrm{~g}\end{array}$ & 軟 & - & - & 大正 2 年 \\
\hline 7 & $\mid$ & 5 & 4 & 麻夤大 & - & - & 軟 & 蒙色 & - & 大正 2 年 \\
\hline 8 & 暚 $\overline{\bar{\pi}}$ & 22 & 1 & 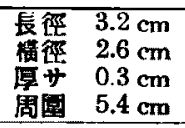 & 扁平腈圆形 & $1.5 \mathrm{~g}$ & 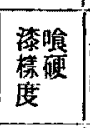 & 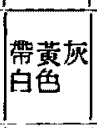 & 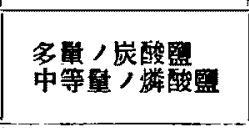 & 大正13年 \\
\hline 9 & 池 田 & 24 & 12 & 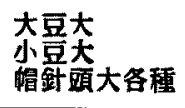 & - & - & - & - & - & 昭和 4 年 \\
\hline 10 & 池 田 & 22 & 7 & $\begin{array}{l}\text { 大豉太 } \\
\text { 棺釬頭大各種 }\end{array}$ & - & - & - & - & 一 & 昭和 4 年 \\
\hline 11 & 河 田 & 49 & 1 & 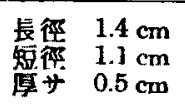 & 觶頭形 & $0.6 \mathrm{~g}$ & 硬固 & $\begin{array}{l}\text { 剽䋵 } \\
\text { 福色 }\end{array}$ & 「フィプリン」 & 昭和 6 年 \\
\hline 12 & 伊 藤 & 40 & 1 & 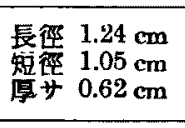 & 滆平叠圆形 & $\begin{array}{c}0.6 \mathrm{~g} \\
(\text { 摘出時) } \\
0.564 \mathrm{~g} \\
(\text { 乾燥檍) } \\
\end{array}$ & 淞々硬 & 灰白色 & 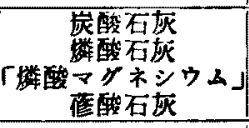 & 昭和12年 \\
\hline 13 & 几 & - & 1 & 龜頭大 & 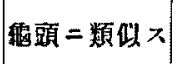 & - & - & - & - & 大正 2 年 \\
\hline 14 & 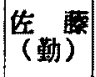 & & & モ，如 & 郭細不明 & & & & & 明治41年頁 \\
\hline
\end{tabular}

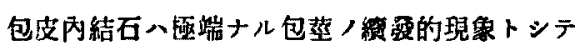
形成セラルルモノナレドモー般䎵尿器系結石磪生

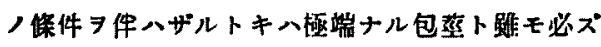
シモ包皮內結石习生ズルモハト限ラザルモノナ

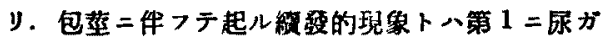

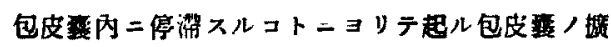
張，第 2 二包皮內結石 形成是ナリ，本結石形成 =网スル Lewin 及ビ Zahn 雨氏，研究及ビ其，

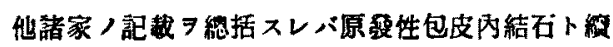

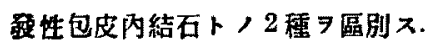

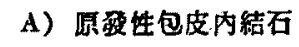

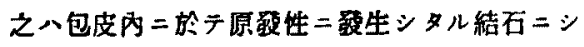

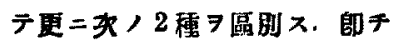

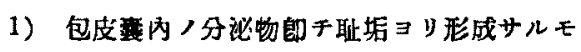

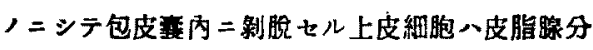
谈物（Sinegma）.下共二一小㴔习形成シ，之二尿 中ノ石灰浸透讴着シテ結石引構成スルモノナリ。

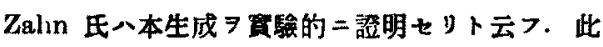
電 結石ニテリテ八重量甚ダ輕ク新鲜時二於テ八

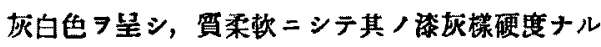

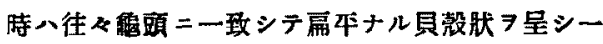
方八凹面，他方八凸面 ヨ有スルコトナり(I.ewin).

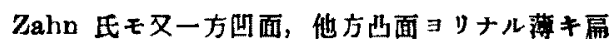
平ナル「時計ガラス」/如キ形ノモノヨ見タリト 辄告セリ． I.ewin 氏八斯儿結石ヨ空中ニテ数時間

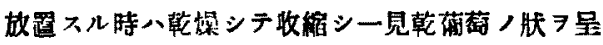


セルフ見タット云フ、又其八㽖斷面9見ル二同心 生ノ輸首习認メズト。

钼微鏡的所見八通常上皮細胞「コレステリン結 晶」立二石灰习見ル。文之二細菌 アリ. 化悬的所見トシテ八脂肪, 遊襍脂肪酸，石

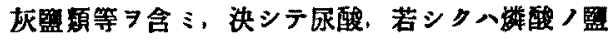
類习含マズ。

2）包皮內二落留七ル尿二由來セルモノニシテ

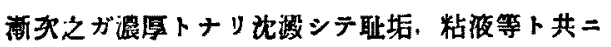

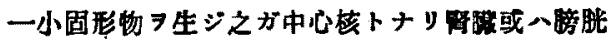
結石卜同一/方法二ヨリ䉼次結石习構成スルをノ

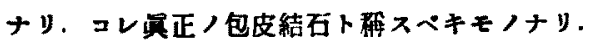

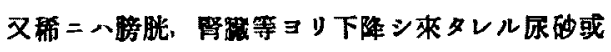
八小石片ガ中心核ヨナシ結石ヨ生ズルコトアリ。

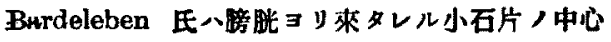

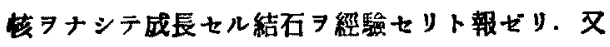
外部 $コ$ り包皮內二入リタル固形物ガ中心核 コトアリ. 宮绮氏八小兒時代二惡战二包皮震内二 砂习入レテ遊ビタル者後年ニ至りテ包皮結石习箃 生セル刚 习報告セルモ此患者二於テ八砘稙が結石 形成二對シ其/核心トナレルヤ否ヤ八宮崎氏自身

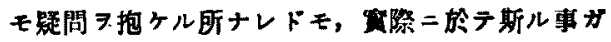
有得ルモハト考へラル。

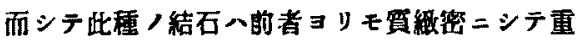
量著シク重ク硬度遥二级り，灰白黄色ヨ帶ビ且又

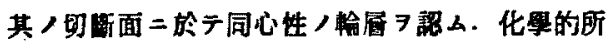
見トシテハ多クノ場合尿酸石灰、宸酸石灰、橉酸 石灰、「矮酸アムモニアクマグシヤ」等 ヨ見ル。

\section{B. 毁性包皮結石}

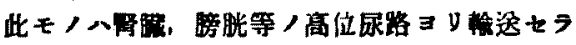
ルル際包蕉タメ二外部二排出セラルルコトナク 一時包皮慗肉二筷頓女ルニヨルモノナy. 此種結

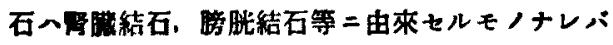

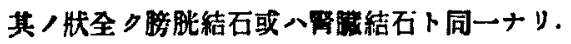

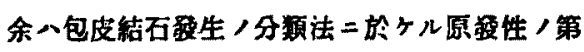

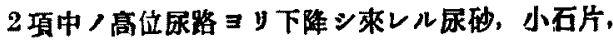
或八外界 ヨり包皮内二入りタル異物

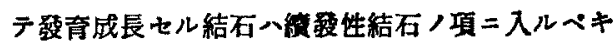
モノナルコト习提唱ス. 何故ナラバ上部ョリ來タ レル尿砂或ハ小石片ヨ中心核トシテ包皮內二於テ

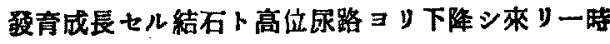
包皮內二節頓セル結石卜，間二八唯結石，包皮內 二濡留セル時間的ノ相臬アル二過ギザル如ク考二

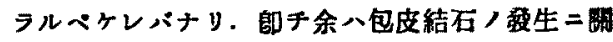

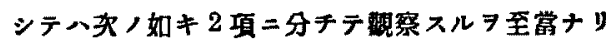
ト考入.

原性包皮結石 72 種二分于，1）包皮菜肉二 於テ耻拮，上皮細胞等 $コ$ リ成儿梚塊物二尿中，石

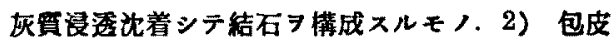

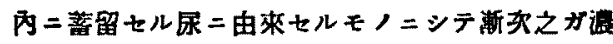
厚トナリ，耻坧、粘液等卜共二一小固形物 7 生シ，

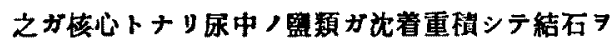
粠成ス几モノ。

破性包皮結石二包含スベキー八高位尿路

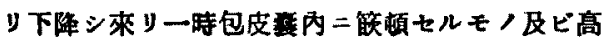

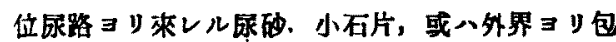
皮焦內二入リタル異物习核心トシテ此處二於テ 萳成长せル結石ナリ

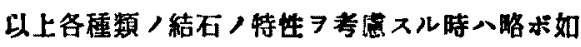
何ナル種類，包皮結石ナルカラ判定シ得ルモノナ y.

\section{6. 末症/症狀}

包皮內結石 存在スル者二於デ先ツ長期間二

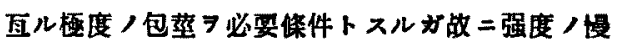

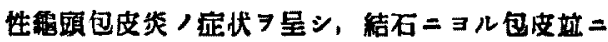

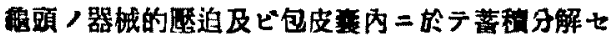
ル尿ノ刺戟 ヨ受ヶテ表皮制脫シテ度烟习來シ，包

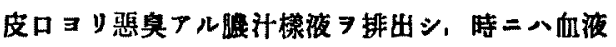

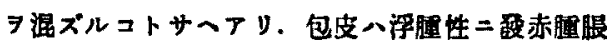




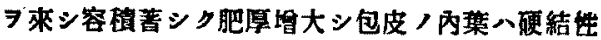

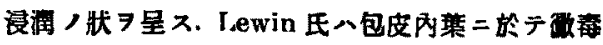

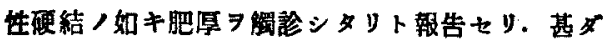
シキニ至リテハ包皮口塽小ナルタメ結石八如何二

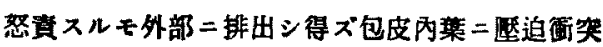

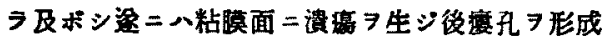
シ之ョリ結石ノ出ッ゙ルコトアリ，Zahn 氏、52葴

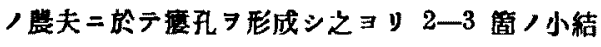
石

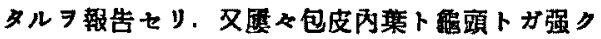

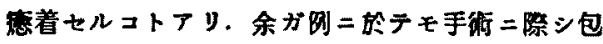

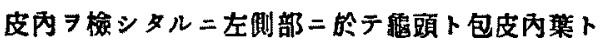

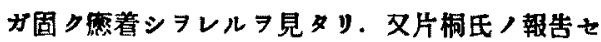
ル例二於ヶルガ如ク結石，容稍大ナル時八画頭， 著シキ退行性萎縮

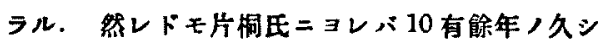
キ間結石ノタメ著シク医縮セラレテ扁本トナリ

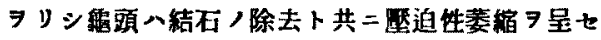
ズシテ直チニ膨出常㮩二復シタリト。蓋シ興味ア

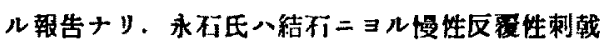

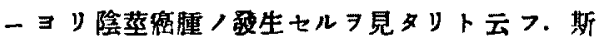
ルモハ八政後二關係スルコト極メテ大ナリ．又

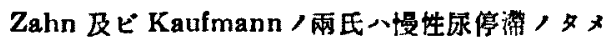

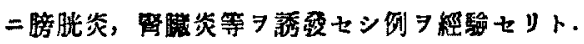

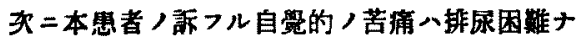
レドモ包花/程度，結不ノ大小，始二其/存在入 ル位置ニョリテ大差アリ．臫于極メテ切期二於デ 一思者八結石，存在スルラ氣付カズ尿線，多少細 クシテ排尿二稳々長時間 コト多シ．而シテ結无八函メテ徐に生長スルモ ノ多シ. 片桐氏ニヨレバ患者／結石／存在 $ヨ$ 始

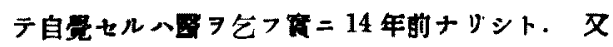

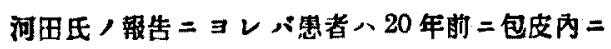
硬固ナル物アル二氧付キタリト，之二㓡河田氏

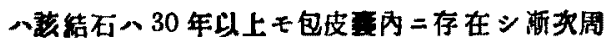

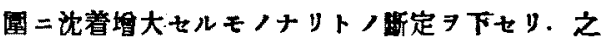

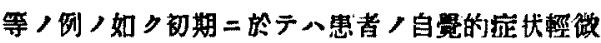
ニシテ斯クモ長年月 7 要シテ結石，莈育成長スル コトアリ，從テ斯儿堨合二八患者八左程ノ苦㵝 柝へズシテ經過スルコトー般ナリ．然レドモ包皮 整八如キ狄小ナ儿場所二於テ八結石八無限二成辰 スル能、ズ，加之包葓／度增市，而モ結石ノ自然

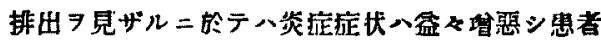
何レノ日ニカ大ナル苦痛习訴フル時フラム．特二 排尿時痛，排尿困蜼 シ㹬フル二至ラム．即于尿線 八直射せズ甚ダシキ二至りテ八排尿二際シテ尿線 シナサズシテ尿八滴濯スルニ至ルコトフリ。余カ 例に於テモ包皮口八爾メテ獭小トナリ尿八常二滴

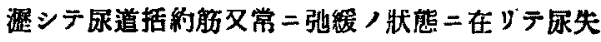
慗ノ状ヨ旺シ居レリトイフ。

灭二又結石小ナル時二於テ八通常媾接障碍 $习$ 起 サザルモ結石增大スルト共二性態，澱退 ミナラズ激シキ艾接障碍

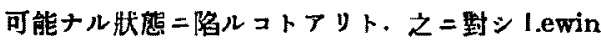

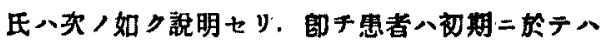

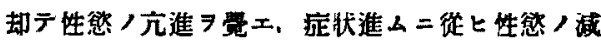

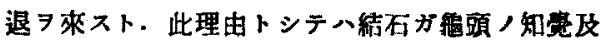
ビ血管運動神經二塺迫习及ボシ，其八結果最初八

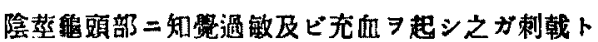
ナり珄倠ノ穴進ヨ來スモノニシテ，小胃ニ於テモ

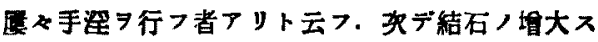

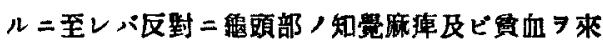

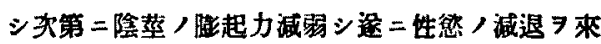
ストイフニアリ，余ノ侧二於テ八偝接二際シテ多 少昸痛习感ズル程度ナリキ。

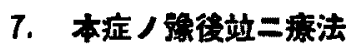

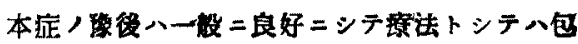
皮切除街或八背側包皮切離法 7 施シ結石 7 除去

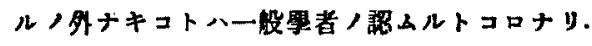


然レドモ此手得的療法二關シテ最も注意スべキコ 卜 八本应ノ如キ函メテ少数ナル報告例中而モ其ノ 2 例二於テ死ノ轉歸ヨトレルモノフリシト．其ノ 1 例 一 Kochel 氏 報告セルヒノニシテ包皮留側 切開 7 加一結石习除去シタル二泪後 3 日ニシテ患 者八敗血庭习起シ終二死亡セりト云フ。他１恻 八Zahn 氏ノ跟告セルモノニシテ氏八單二包皮切 開习施シ結石习除去シタルコトノミニヨリ患者八 死亡セリトイフ．斯ル原因八未ダ不詳ナレドモ此

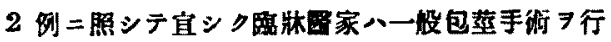
フ如キ態度 7 以テセズ，本症二於テ八特二生意 7 拂七可及的早期二手術的二結石 7 除去スル 7 必要 トスル八勿論, 消毒二對シテモ透漏ナキヤウ努メ

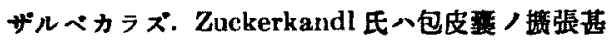

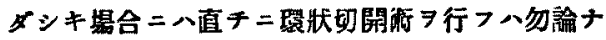

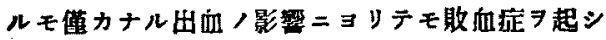
悲シキ死八南㩆マトルコトフルニヨリ先ッ局所，

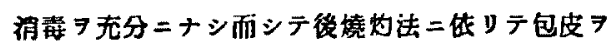

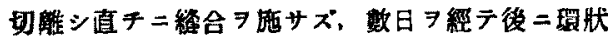
切開猃 ヨ行フコトヨ推獎セり。

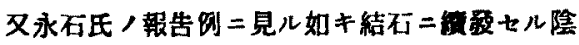
蕉究腫, Zahn 及ビ Kaufman 雨氏ノ侧二見儿膀

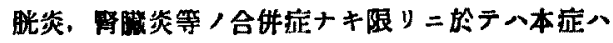
一般二經過良好ニシテ上述ノ手術的療法二依り 10 日前後ニシテ完全ニ治雭スルモノナリ。

\section{8. 總括及ビ結論}

以上述へタル所尹要約スル二余，例八记篗 二件フ排尿障碍及ビ㓌邀帶部二於ケル硬結 フ主訴ト七ル40歲，農夫ニシテ，生來中等度 ノ先天性包蕉习有七シ力約 5 年前 $コ$ 慗帶部 二無痛性ノ小結節現ハレ，又包皮叭小トナ ソ、爾來排尿，快利七ザル二至ル。特 $=2$ 䉪

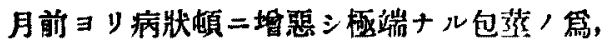

排尿著シク障碍セラレ絜帶部ノ結節モ琶豆大 以上トナル。視診上包皮八著シクシ發赤腫脹 シ極端ナル包荥二陷レリ．觸診上包皮八浸潤 肥厚シテ硬ク，慗帶部二八骨樣硬度ノ硬結物 7觸ル，包皮口八Charrière Nr. 6 ，消息子 キ辛ウシテ插入三得. 包皮內タ消息スル二固 形硬固物/存在 知り得タリ。依テ環狀包皮 切除䘗ニヨリ結石ヨ除去セり.

摘出結石ハ 1 箅ニシテ長徑 $1.24 \mathrm{~cm}$, 短徑 $1.05 \mathrm{~cm}$, 厚サ $0.62 \mathrm{~cm}$ 算シ, 扁平楕圆形二 シテ灰白色テ呈シ，表面概シテ平滑，質硬ク， 切断面:八同心性/輪屏子認么。其/重量八 $0.6 \mathrm{~g}=$ シテ成分八炭酸石灰，燐酸石灰，「燐 酸マグネシウム」, 恶酸石灰等ナリ。

本結石八5 年前既二發育 7 初メタルモノト 考へラル。而シテ包皮內分泌物及ビ濃縮セル 尿隐類等相集積シテ 1 小塊 形成シ，之キ中 心核トシテ篮類，沈着發有シテ今日ニ至レル モノナラム.

余八更二東西ノ文缺き寥照シ，特二本邦， 症例二就テ其ノ總括的钼察 7 行ヒタリ.之ヨ リ結諭フ求ムレバ次ノ如シ。

1) 大正 9 年ヨリ昭和 12 年 8 月末二至ル

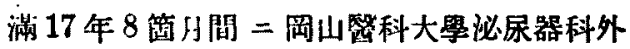
來テ訪レタル患者總數ハ10420名ニシテ䎵尿 器系結石患者數ハ455名ナリ。而シテ包皮結

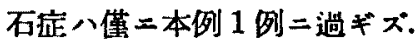

2）本邦二於ケル包皮結石应，報告例、余 ノ知レル籍園二於テハ余，例テ合七テ僅カニ 14 例ナリ。

3）本邦二於々ル包皮結石症／年路的關係 八50 藏以上 4 例, 40 年代 3 例, 20 年代 4 例, 10 年以下 1 例, 年齢不明 2 例ナッ. 


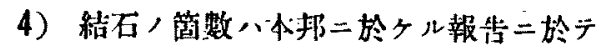

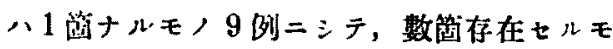
ハ4例, 不明ナルモ，1例アリ. 而三テ其

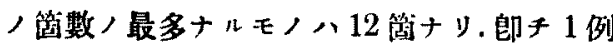

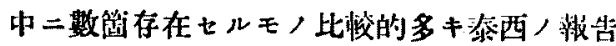
例卜異ナル所ナリ。

5）包皮內結石 1 䈱，重量八各证例二於テ 可ナり著シキ相違アルモ概シテ云へバ一般尿 路結石ニ比シテ小ナり。而シテ本邦二於テ最 大ナルモ，八橋本氏，跟占セル42.0 g 二

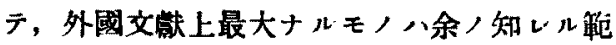
图二於テ，Couilland 氏， $645 \mathrm{~g}+\nu$.

6) 本結石八其ノ發生機轉ヨリシテ 2 槛二 大别シ得べシ。郎手， 1 八所調原發性包皮 結石ニシテ他八續發性結石ナり．前者八包皮

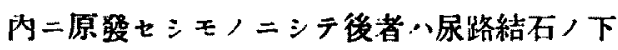
降二起因七ルモノナリ。而シテ前者い更二其 ノ核ノ性狀ヨリシテ2ッニ區別シ得べ。郎 （1），結石，核ガ耻垢，上皮細胞等 $コ$ 成 レルモノニシテ之二尿中/石灰カ浸透沈塤七

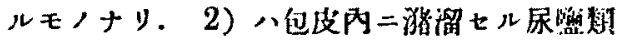
カ最初其/核心トナリ，結石形成七ルモ，
ニシテ更二之二耻振，上没細胞，粘波等，卒

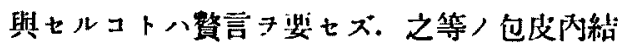
石ハ各々将長アリ，之ニョツテ其ノ成因ョ想 像三得べシ。而シテ余方例八最嵝，結石二屡 スルモノト思惟七ラル。

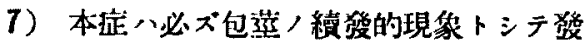
生スルモノナレドモ，極端ナル包莖卜踓モ尿 石發生，保件タ俳ハザル時ハ必ズシモ包皮內 結石フ形成スルモノト八限ラズ.

8）本症／療法八極メテ簡單ナルモー般出 䓰手術 7 行フ如キ態度

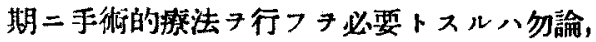
消毒二對シテハ特二逍漏ナキャウ努ィザルべ カラx:

9）長大ナル包蒙フ有スル者二對シテ八包

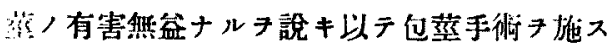

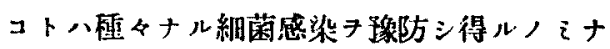
ラズ他皮絬石，形成子米然二防止シ以テ一石 二岛ノ利アリト信ズ.

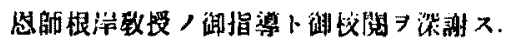

\section{主 要 文 跃}

1) Couilland, Z. n. Ztschr. f. urol. Chirur., Bd. 31, S. 250, 1931.

2）橋本，日本外科學算

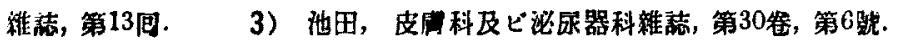

4) Ilinsky, Z. n. Ztsehr. f. urol. Chirur, Bd. 37, S. 323, 1933. 5) Ingraham, The Journ. of the Amer. Med. Associat.,

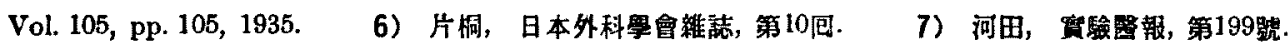
8）Lewin, Berliner klin. Wschr., No. 13, S. 177, No. 14, S. 197, $1979 . \quad$ 9) 宮喻，士肥数授大學

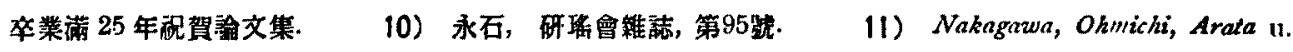
Higaki, Arbeit. aus d. med. Universit. zu Okayama, Bd. 1, S. 444. 12）中野, 皮科及ビ议尿

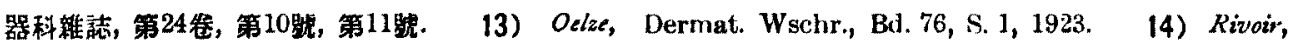

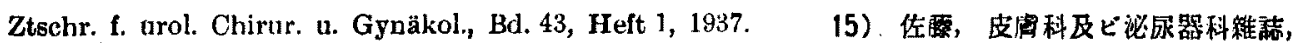

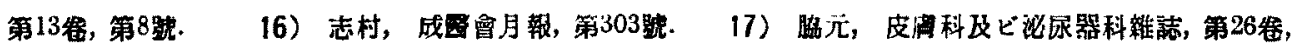

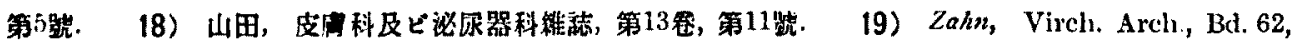
$\therefore 560$, 1575. 20) Zuikerkandl, Iandhuch d. Urol, Bil. III, S. 471. 